African Crop Science Journal by African Crop Science Society is licensed under a Creative Commons Attribution 3.0 Uganda License. Based on a work at www.ajol.info/ and www.bioline.org.br/cs DOI: http://dx.doi.org/10.4314/acsj.v25i1.9

\title{
WILD AND DOMESTICATED MUSHROOM CONSUMPTION IN NIGERIA
}

\author{
O.M. ADEDOKUN and C.A. OKOMADU \\ Department of Crop and Soil Science, Faculty of Agriculture, University of Port Harcourt, PMB 5323 \\ Choba, Rivers State, Nigeria \\ Corresponding author: olutayo.adedokun@gmail.com, olutayo.adedokun@uniport.edu.ng
}

(Received 20 September, 2016; accepted 10 February, 2017)

\begin{abstract}
Research on mushroom and mushroom products is dynamic with global increasing interest. The natural habitat of mushrooms being the wild, it is imperative to cultivate mushroom domestically in order to make it available to the populace. The aim of this research was to assess the perception of consumers to consumption of wild and cultivated mushrooms in Port-Harcourt, Nigeria; and validate nutrition quality of wild and cultivated mushroom. A survey was conducted using structured mixed questionnaires, to gather perception of 90 respondents on consumption of wild and cultivated mushroom. Lentinus squarrosulus (Mont.) Singer, sourced from the wild was cultivated using standard methods for mushroom cultivation and both mushrooms were analysed for proximate chemical and mineral components. Result revealed that $47.8 \%$ of the respondents got introduced to mushroom consumption through family settings; $53.3 \%$ of respondents were conversant with wild mushrooms, $27.8 \%$ with cultivated and $16.7 \%$ with both. A total of $71.1 \%$ was informed about mushroom poisoning; while $28.9 \%$ had no knowledge about it at all. About $45.6 \%$ sourced mushroom from the wild and $33.3 \%$ from mushroom farms. Only $28.9 \%$ consumed mushrooms for over 10 years; whereas, $13.3 \%$ had never tasted mushrooms. Year-round consumption was only by $12.2 \%$; while $57.8 \%$ consumed mushroom once in a while. However, if cultivated mushrooms could be made available, $58.9 \%$ indicated interest in mushroom consumption. If nutrition facts of wild and cultivated mushrooms are the same, $38.9 \%$ were willing to consume cultivated mushrooms, $30.0 \%$ wild, $20.0 \%$ both and $11.1 \%$ insisted on no consumption. On the other hand, if nutrition analysis reveals different nutrition parameters for both types of mushrooms, $43.3 \%$ opted for cultivated mushroom, $42.2 \%$, wild; $12.2 \%$ both; while $2.2 \%$ would eat neither of the mushrooms. Generally, from the results, both mushrooms possess adequate nutritive values; though, of all the parameter analysed, only zinc was significantly different $(\mathrm{P}<0.05)$. For some of the parameters (potassium, zinc, phosphorus, calcium, total ash, crude fat, crude protein) the wild mushroom had higher values than the cultivated; whereas for other parameters (iron, manganese, magnesium, carbohydrates, crude fiber), the cultivated values were higher. Both mushrooms were relatively low in fat, ash and moisture; and high in carbohydrate, crude fiber and crude protein. Both mushrooms were high in minerals. There is no significant difference between the nutrition facts of the wild and cultivated test mushrooms.
\end{abstract}

Key Words: Consumption pattern, Lentinus squarrosulus, nutrition, perception, wild mushroom

\section{RÉSUMÉ}

La recherche sur les champignons et les produits derivés est dynamique avec un intérêt croissant mondiale. L'habitat naturel des champignons étants auvage, ils'avère impératif de domestiquer les champignons afin de le rendre disponible à la population. L'objectif de cette recherche était d'évaluer la perception des consommateurs à la consommation de champignons sauvages et ceux cultivés à Port-Harcourt, au Nigeria; et de valider la qualité nutritionnelle des champignons sauvages et cultivés. Une enquête étaitmenée à l'aide d'un questionnaire mixte structuré, afin de recueillir la perception de 90 répondants sur la consommation de champignons sauvages et 
cultivés. Lentinus squarrosulus (Mont.) Singer, d'origines auvage était cultivés en utilisant des méthodes standard pour la culture des champignons et les deux analysés pour obtenir des données sur leurs composants chimiques et minéraux. Les résultats d'analyse ont révélé que $47.8 \%$ des répondants étaient déjà habitués à la consommation de champignons au niveau familial, 53,3\% étaient familiarisés aux champignons sauvages, 27,8\% les cultivaient chexeux et $16,7 \%$ étaient familiers aux deux. Au total, $71.1 \%$ ont été informés de l'intoxication par les champignons; tandis que $28.9 \%$ ne connaissaientrien à cesujet. Environ $45.6 \%$ de champignons consommés étaient de source sauvage et $33.3 \%$ cultivés chez eux. Seuls $28.9 \%$ consommaient déjàles champignons depuis plus de 10 anstandis que $13.3 \%$ n'avaient jamais mangéles champignons. La consommation annuelle était seulement $12.2 \%$ pendant que $57.8 \%$ consommaient les champignons occasionnellement. Toutefois, si les champignons cultivés pouvaient être disponibles, $58.9 \%$ ont indiqué leur intérêt à consommer les champignons. Si les preuvessur la nutrition par les champignons sauvages et les champignons cultivés sont les mêmes, 38,9\% souhaitaientc onsommer les champignons cultivés, $30,0 \%$ sauvages, $20,0 \%$ et $11,1 \%$ ont insisté sur la nonconsommation. D'autre part, si l'analyse nutritionnelle révèle des paramètres nutritionnels différents pour les deux types de champignons, $43,3 \%$ préféraientles champignons cultivés, $42.2 \%$ les sauvages; $12.2 \%$ les deux, tandis que $2.2 \%$ ne préféraientaucun des deux. D'une manière générale, les résultats indiquent que les deux types de champignons possèdent des valeursnutritivesadéquatesbien que de tous les paramètres analysés, seul le zinc était significativement différent $(\mathrm{P}<0.05)$. Pour certainsdes paramètres (potassium, zinc, phosphore, calcium, cendretotale, graisse brute, protéine brute), les champignons sauvages présentaient des valeurs plus élevées que celles cultivées alors que pour d'autres paramètres (fer, manganèse, magnésium, glucides, fibres brutes), les champignons cultivés presentaient des valeurs les plus élevées. Les deux champignons étaient relativement faibles en matières grasses, cendres et de l'humidité et riche en hydrate de carbone, en fibres et protéines brutes. Encore plus, les deux champignons étaient riches en minéraux. Il n'y a pas de différence significative entre les faits nutritionnels des champignons sauvages et cultivés testés.

Mots Clés: Consommation, Lentinus squarrosulus, nutrition, perception, champignon

\section{INTRODUCTION}

Research on mushroom cultivation and usage is dynamic, with new discoveries unfolding by the day. This unique vegetable is increasingly global in demand. Recent research reported various uses of the crop (Summers et al., 2015; Singdevsachana et al., 2016; Bemas and Jaworska, 2016; Robak et al., 2016). Mushrooms have their natural habitat in various places, ranging from farm lands, forest and newly cleared lands, to cut pieces of wood found in several places.

In these natural habitats, availability of mushrooms is seasonal, depending on the species; some may be available just at the onset of rains, others during the rains; yet others when the rains are winding up. This leaves a gap for lovers of mushrooms during dry season or summer period, and underscores the need for mushroom cultivation (domestication).
Furthermore, there are risks associated with mushroom hunting, the greater one being mushroom poisoning which could cause various discomfort ranging from mild/severe gastrointestinal disturbances to outright death (Stamets, 2000).

Mushroom cultivation is the conversion of agricultural wastes to useful products of various uses using tissue culture techniques. Agricultural wastes, which otherwise would have been burnt or constitute a nuisance to the ecosystem (Bano et al., 1993; Buswell et al., 1996; Cohen et al., 2002) become useful to produce useful vegetables suitable for all gender classes.

Mushroom cultivation dates back to the $17^{\text {th }}$ Century (Anonymous, 2016) and had since made tremendous improvements to-date. Although mushroom cultivation and consumption are globally being encouraged, with new products being introduced and formulated, there is a perception among many 
consumers of mushrooms in Nigeria that cultivated mushrooms are not as nutritious as wild mushrooms. This is often believed, and affects consumption behavior of cultivated mushroom. The aim of this study was to assess perception of consumers of wild and cultivated mushroom; and then scientifically evaluate the nutrition facts of both wild and cultivated mushrooms.

\section{MATERIALS AND METHODS}

Lentinus squarrosulus was sourced from Aluu village, in Port-Harcourt, Rivers State in Nigeria. The mushroom was found growing on dead Gmelina arborea, a hardwood commonly known as beech wood or white teak. Tissue culture and spawn of the mushroom were carried out using modified standard methods (Stamets, 2000; Oie, 2016). The mushroom was cultivated on sawdust of Khaya ivorensis and Gmelina arborea obtained from a local sawmill. Using a mixture of sawdust, rice bran and lime as bulk substrate in the ratio 10:1:0.2, L. squarrosulus sourced from the wild was produced.

Mushroom consumption. A survey was conducted in Port-Harcourt, Nigeria using convenience sampling methods. Structured mixed format questionnaires were administered to assess awareness and perception to wild and cultivated mushroom consumption. Key parameters in the questionnaire included biodata, awareness about edible and poisonous mushrooms, mode of awareness, consumption history, wild or cultivated preferences, among others. Responses from 90 respondents were used for the purpose of this research. Of this number, $73.4 \%$ were civil and public servant. Up to $15.6 \%$ were students and $11.1 \%$ business owners.

Data analysis. Descriptive statistics such as frequency counts, means and percentages were employed to describe parameters in the questionnaires.

Proximate chemical and mineral analyses. The originally wild mushroom as well as the cultivated mushroom were analysed for proximate chemical and mineral contents. Proximate chemical composition was determined using standard methods as described by Barros et al. (2008). Minerals ( $\mathrm{Ca}, \mathrm{Mg}, \mathrm{K}, \mathrm{P}, \mathrm{Mn}, \mathrm{Fe}$ and $\mathrm{Zn}$ ) were determined using procedures for determination of microand macro- elements in food and feed samples, with the aid of Atomic Absorption Spectrophotometer (AAS) (García et al., 2008).

Data obtained were analysed statistically using analysis of variance (ANOVA) procedure of SAS Statistical Software Package (2001).

\section{RESULTS}

The survey. Table 1 and Figure 1 display responses from the respondents. The Table also shows the geographical spread of the respondents, along the four regions of Nigeria, namely: northern, southern, eastern, and western regions. Only two of the respondents had not heard of mushroom before the questionnaire was administered to them. The mode by which individuals got introduced to mushroom consumption varied (Fig. 1); however, awareness through family members was $31.1 \%$ higher than that from friends; and $46.7 \%$ higher than awareness through religious affiliation, which was the least.

Figure 1 further revealed responses in the order of $53.3 \%$ conversant with wild mushrooms, $27.8 \%$ with cultivated mushrooms, and $16.7 \%$ with both wild and cultivated mushroom. Up to $71.1 \%$ were informed about mushroom poisoning; while $28.9 \%$ were unaware about this characteristic. A total of $45.6 \%$ mushrooms were sourced from the wild and $33.3 \%$ from mushroom farms. Only $28.9 \%$ had been consuming 
TABLE 1. Bio-data for respondents and source of mushroom information in a study in Nigeria

\begin{tabular}{lll}
\hline Frequency & Percentage (\%) \\
\hline
\end{tabular}

Age (years)

\section{$15-25$}

26-35

$36-45$

$46-55$

$>56$

$\operatorname{Sex}$

Male

Female

Religion

Christian

Islam
13.3

24.4

35.6

21.1

5.6

\section{Occupation}

$\begin{array}{lrr}\text { student } & 14 & 15.6 \\ \text { public servant } & 66 & 73.4 \\ \text { Business } & 10 & 11.1 \\ \text { Region } & & \\ \text { North } & 9 & 10.0 \\ \text { South } & 44 & 48.9 \\ \text { West } & 18 & 20.0 \\ \text { East } & 19 & 21.1\end{array}$

Informed about mushroom

Yes

No

2

\section{Mode of information}

\begin{tabular}{lrr} 
Internet & 3 & 3.3 \\
Family & 43 & 47.8 \\
Farming & 6 & 6.7 \\
Media & 4 & 4.4 \\
& & \\
Excursion/seminar & 6 & 6.7 \\
& & \\
Study & 7 & 7.8 \\
Friend & 15 & 16.7 \\
Religious affiliation & 1 & 1.1 \\
N/A & 5 & 5.6 \\
\hline
\end{tabular}

NA = Not applicable mushrooms for over 10 years; whereas $13.3 \%$ had never tasted mushrooms.

Year-round consumption was only $12.2 \%$; while $57.8 \%$ consumed mushroom once a while. However, if cultivated mushrooms could be available to households, $58.9 \%$ indicated interest in mushroom consumption. On the other hand, if nutrition facts of wild and cultivated mushrooms were the same, $38.9 \%$ were willing to consume cultivated mushrooms, $30.0 \%$ wild, $20.0 \%$ both and 11.1 insisted on no consumption. However, if nutrition analysis reveals different nutrition parameters for both mushrooms, $43.3 \%$ opted for cultivated mushroom, $42.2 \%$ wild, $12.2 \%$ both; while $2.2 \%$ would eat neither of the mushrooms. Reasons for choice of wild or cultivated mushroom for consumption are represented in Table 2.

Reasons gathered for discontinuation of mushroom consumption from the $27.8 \%$ respondents who had had to stop mushroom consumption included loss of interest $(24.0 \%)$, unavailability -seasonal/insufficient supply for cultivated $(68.0 \%)$, mushroom poisoning $(4.0 \%)$ and expensive cost of cultivated mushroom compared with free wild mushrooms $(4.0 \%)$.

Nutrition analysis. Results for nutrition parameters for both wild and cultivated mushrooms are represented in Tables 3 and 4. Generally, both mushroom types possessed adequate nutritive values, though, there was no significant difference $(\mathrm{P}>0.05)$ between parameters analysed for proximate facts. However, for minerals, only zinc was significantly different $(\mathrm{P}<0.05)$. For some of the parameters (Table 4), the wild mushroom had higher values than the cultivated. For other parameters (iron, manganese, magnesium, carbohydrates and crude fiber), the cultivated values were higher. Both mushroom types were relatively low in fat, ash and moisture, but higher in carbohydrate, crude fiber and crude 


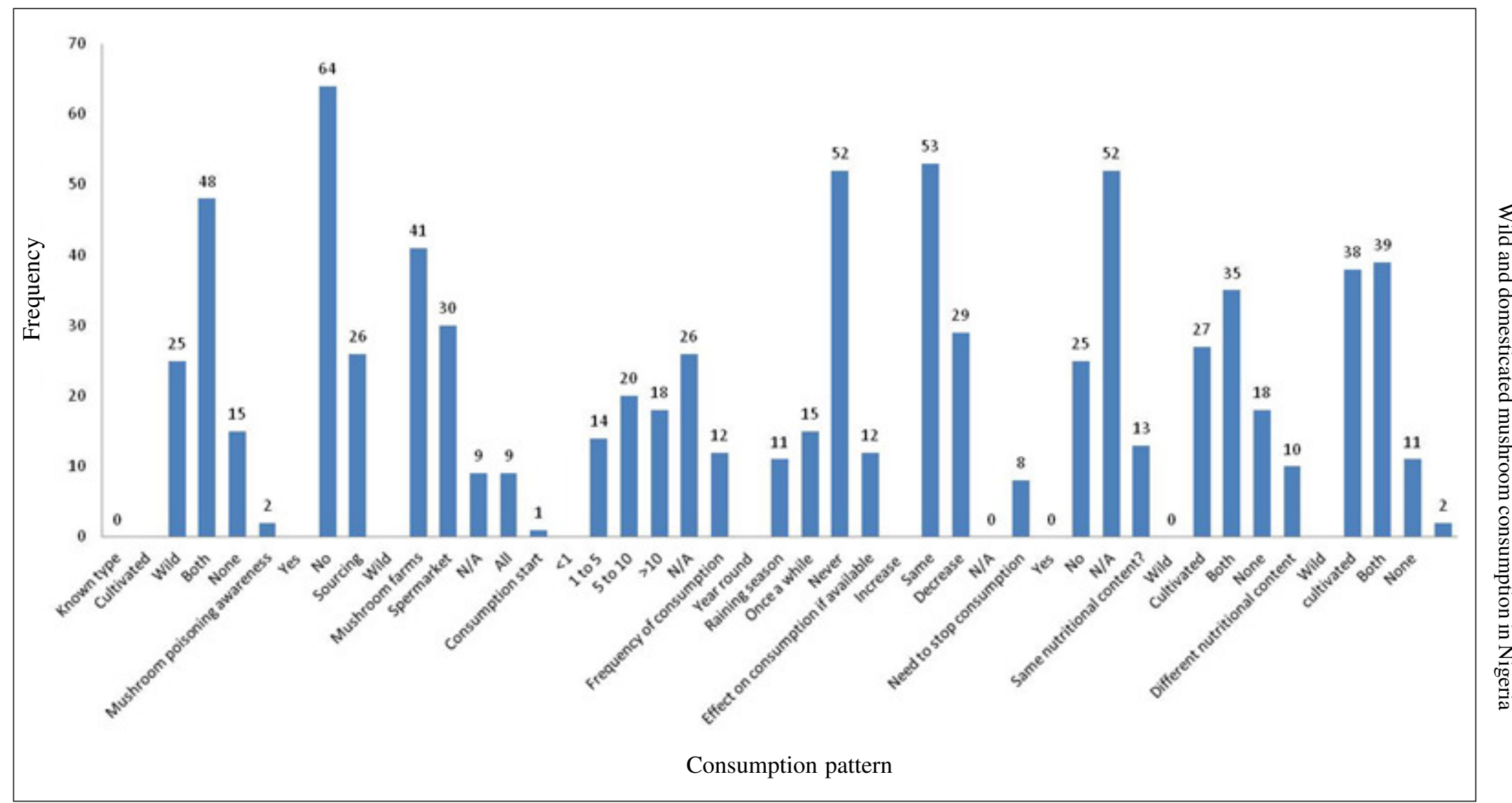

Figure 1. Consumption history of wild and cultivated mushrooms in Nigeria. 
TABLE 2. Reasons for preference of wild or cultivated mushroom by communities in Nigeria

\begin{tabular}{|c|c|c|}
\hline Wild & Cultivated & Both \\
\hline Natural & Safety and health & Nutritious \\
\hline Less expensive & Reliable source & Medicinal \\
\hline Nutritious & Hygienic & \\
\hline Delicious & *May contain hazardous chemicals & \\
\hline Freshness & Nutritious & \\
\hline Tastier & Readily available year round & \\
\hline Absence of additives & Natural taste & \\
\hline Organic & Easy access to commercial farm & \\
\hline May be harvested free & $\begin{array}{l}\text { * May be genetically modified } \\
\text { Free from poisonous chemicalswhich may be present } \\
\text { on sites where wild mushrooms are sourced } \\
\text { Medicinal } \\
\text { Mere interest } \\
\text { May be easily fortified }\end{array}$ & \\
\hline
\end{tabular}

* Addressed in discussion

TABLE 3. Proximate chemical composition of wild and cultivated Lentinus squarrosulus in Nigeria

\begin{tabular}{lrrrrrr}
\hline Mushroom & \multicolumn{1}{c}{$\begin{array}{c}\text { Moisture } \\
(\%)\end{array}$} & $\begin{array}{r}\text { Crude protein } \\
(\%)\end{array}$ & $\begin{array}{c}\text { Crude fat } \\
(\%)\end{array}$ & \multicolumn{1}{c}{$\begin{array}{c}\text { Crude fiber } \\
(\%)\end{array}$} & \multicolumn{1}{c}{$\begin{array}{c}\text { Total ash } \\
(\%)\end{array}$} & \multicolumn{1}{c}{$\begin{array}{r}\text { CHO } \\
(\%)\end{array}$} \\
\hline Wild & $10.820 \pm 0.10$ & $23.34 \pm 3.44$ & $3.96 \pm 0.57$ & $24.29 \pm 2.63$ & $7.53 \pm 1.75$ & $30.60 \pm 2.55$ \\
Cultivated & $11.57 \pm 0.49$ & $22.56 \pm 0.56$ & $3.12 \pm 0.47$ & $25.34 \pm 0.93$ & $7.37 \pm 0.21$ & $31.00 \pm 0.06$ \\
T-test & 1.85 & 0.22 & 1.12 & 0.38 & 0.09 & 0.16 \\
$($ P $>0.05)$ & $0.11^{\mathrm{NS}}$ & $0.83^{\mathrm{NS}}$ & $0.31^{\mathrm{NS}}$ & $0.72^{\mathrm{NS}}$ & $0.93^{\mathrm{NS}}$ & $0.88^{\mathrm{NS}}$ \\
\hline
\end{tabular}

NS $=$ Not significant

protein (Table 3). Results for minerals (Table 4) indicated that both mushrooms are high in minerals

\section{DISCUSSION}

Bio-data of respondents showed their distribution across age, gender, religion and occupation are presented in Table 1 and Fig. 1). The fact that all age and gender groups involved in this study indicated mushroom awareness, buttressed the fact that mushroom consumption in Nigeria is gaining recognition and becoming a subject of interest (Adedokun et al., 2016). Only two persons out of the 90 respondents had no knowledge about mushrooms. The influence of family and friends in mushroom consumption was evident in rejoinders, however; mushroom growers may need to engage in the use of other means 
such as internet, media, seminars and workshops to launch a better campaign.

Knowledge about wild mushroom was higher than cultivated mushroom (Fig. 1). This is understandable as mushrooms have their natural habitat in the wild. Nevertheless, since availability of wild mushroom is seasonal and may have attendant risks, awareness about cultivated mushrooms should be widely publicised. It may be necessary to keep the populace up to date with information about mushroom poisoning as the percentage of individuals who did not have this information is relatively high. This could promote mushroom cultivation.

It is quite interesting to know that about $33.3 \%$ of respondents obtained mushrooms from commercial farms; this reinforces the fact that mushroom farming is gradually growing (Adedokun et al., 2016). Consumption history revealed that, although a large proportion $(71.1 \%)$ of respondents had knowledge about mushroom consumption, only a few $(12.2 \%)$ consumed it year-round. A greater percentage $(57.8 \%)$ consumed it once in a while. There is, thus need for basic awareness about nutritional benefits from mushrooms. This will raise the knowledge of individuals and enable more persons to partake of the benefits mushrooms possess.

Awareness may furthermore be necessary, considering the reasons stated for preference of wild over cultivated mushrooms (Table 2). Some respondents expressed concern that cultivated mushrooms may contain hazardous chemicals, and may be genetically modified. These views are not necessarily the case as use of hazardous chemicals is not encouraged in mushroom cultivation and not all cultivated mushrooms are genetically modified. There may be a need for regulatory bodies to monitor mushroom cultivation process and ensure compliance to standards.

It is remarkable to note that approximately $60 \%$ of respondents were willing to increase mushroom consumption, provided mushrooms were readily available (Fig. 1). This is good news to commercial mushroom growers, who 
could produce mushroom year-round as well as promote mushroom farming and cultivation. Also, individuals who had stopped mushroom consumption, mainly for non-availability of the product, may resume consumption of produce with availability.

Nutrition facts of wild and cultivated being the same, cultivated mushroom was preferred over wild mushroom due to health and safety issues, as well as year-round availability, among other reasons. This underscores the need to improve upon commercial mushroom production. Even in the event that nutritional composition was different, cultivated mushrooms were still preferred, although the line of preference was thin (Fig. 1).

Analysis of wild and cultivated mushrooms for proximate chemical composition indicated the two mushrooms were equally nutritious (Tables 3 and 4). This corroborates with the work of several workers (Kadiri and Fasidi, 1992; Barros et al., 2008; Okhuoya et al., 2010; Ahad et al., 2014; Valverde et al., 2015) who reported that mushrooms are rich in nutrients. Interestingly, the wild mushroom did not possess more than one of the analysed parameters in proportions significantly different from the cultivated ones. Analysis was, however, limited to proximate chemical composition and mineral analyses. This should allay fears by concerned individuals that cultivated mushrooms are less nutritional than wild mushrooms. This observation is similar to that of Barros et al. (2008) that wild and cultivated mushrooms possess essential nutrients. While the wild mushroom was higher in crude protein, crude fat, total ash, calcium, potassium, phosphorus and Zinc; the cultivated mushroom possessed higher values in moisture content, crude fiber, carbohydrate, magnesium, manganese and iron, although, in this study, the cultivated mushroom was produced from its wild counterpart.

\section{CONCLUSION}

There is no significant difference between the nutrition facts of the wild and cultivated test mushroom. It is anticipated that the findings of this research will positively influence the perception of mushroom consumers, improve their buying behavior and the market size.

\section{REFERENCES}

Adedokun, O.M., Kyalo, M., Gnonlonfin, B., Wainaina, J., Githae, D., Skilton, R. and Harvey, J. 2016. Mushroom: Molecular characterization of indigenous species in the Niger Delta region of Nigeria. European Journal of Horticultural Science 81 (5):273-280.

Ahad, S., Tanveer, S. and Malik, T.A. 2014. Bioactive potential of wild edible mushrooms and need for their conservation. Journal of Yeast and Fungal Research 5 (9):110-118.

Anonymous, 2016. Cultivated mushroom. http://www.botany.hawaii.edu/faculty/ wong/BOT135/Lect16.pdf Accessed 29 October 2016

Bano, Z., Shasirekha, M.N. and Rajarathnam, S. 1993. Improvement of the bioconversion and biotransformation efficiencies of the oyster mushroom (Pleurotussajor-caju) by supplementation of its rice straw with oil seed cakes. Enzyme and Microbial Technology 15:985-989.

Barros, L., Cruz, T.,Baptista, P., Estevinho, L.M. and Ferreira, I.C.F.R. 2008.Wild and commercial mushrooms as source of nutrients and nutraceuticals. Food and Chemical Toxicology 46(8):2742-2747.

Bemas, E. and Jaworska, G.Y. 2016. Vitamins profile as an indicator of the quality of frozen Agaricusbisporusmushrooms. Journal of Food Composition and Analysis 49 1-8.

Buswell, J.A., Cai, Y.J., Chang, S.T., Peberdy, J.F., Fu, S.Y. and Yu, H.S. 1996. Lignocellulolytic enzyme profiles of edible mushroom fungi. World Journal of Microbiology \& Biotechnology 12: 537542.

Cohen, R., Persky, L. and Hadar, Y. 2002. Biotechnological applications and potential 
of wood-degrading mushrooms of the genus Pleurotus. Applied Microbiology and Biotechnology 58:582-594.

García, R., Torres, M.C. and Báez, A. 2008. Determination of trace elements in total suspended particles at the Southwest of Mexico City from 2003 to 2004. Review of Chemistry and Ecology 24(2): 157-167.

Oei, P. 2016. Mushroom cultivation IVAppropriate technology for mushroom growers. Eco Consult Foundation, The Netherlands, $520 \mathrm{p}$.

Robak, T.J., Lalal, L.A., Morris, M.J., Williams, B.T., Browne, R.W. and Horvath, P.J. 2016. Acute effects on satiety from white button and shiitake mushroom powder supplementation in a high fat meal. The FASEB Journal 30 (1):692.20.

SAS Institute SAS/STAT. 2001. Guide for Personal Computers Version and Edition Cary North Caroline SAS Institute, USA.
Singdevsachana, S.K., Auroshree, P., Mishrab, J., Baliyarsingh, B., Tayung, K. and Thatoi, H. 2016. Mushroom polysaccharides as potential prebiotics with their antitumor and immunomodulating properties: A review. Bioactive Carbohydrates and Dietary Fibre 7 (1):1-14.

Stamets, P. 2000. Growing gourmet and medicinal mushrooms, Ten Speed Press, California, USA. 574p.

Summers, A.C., Smith, P., Ezike, A., Frutchey, R., Fahle, J., DeVries, E. Taylor, J. and Cheskin, L.J. 2015. A pilot study to compare a mushroom-soy-beef burger to an all-beef burger in school meals. The Journal of Child Nutrition and Management 39(2):1-12.

Valverde, M.E, Hernández-Pérez,T. and Paredes-López, O. 2015. Edible mushrooms: Improving human health and promoting quality life. International Journal of Microbiology 2015 Article ID 376387. 14pp. 